\title{
Composition of Dental Plaque Formed in the Presence of Sucrose and after its Interruption
}

\author{
Jaime Aparecido CURY \\ Aline Soler MARQUES \\ Cíntia Pereira Machado TABCHOURY \\ Altair Antoninha DEL BEL CURY \\ Faculty of Dentistry of Piracicaba, UNICAMP, Piracicaba, SP, Brazil
}

\begin{abstract}
Since dental plaque reservoirs of fluoride $(\mathrm{F})$, calcium $(\mathrm{Ca})$ and inorganic phosphorus $\left(\mathrm{P}_{\mathrm{i}}\right)$ are susceptible to decreases in $\mathrm{pH}$, this in situ crossover study was conducted to test the hypothesis that the low concentration of these ions in plaque, formed in the presence of sucrose, could be attributed merely to the fermentation of this sugar. Eleven volunteers wore palatal appliances containing 6 human enamel blocks during two stages. In each stage, the treatments were either $20 \%$ sucrose solution or distilled deionized water, which were dripped onto the blocks 8 times a day. After 28 days, in each stage, the dental plaque formed on two blocks was collected, the treatment was inverted and after a further 24 and $48 \mathrm{~h}$, the biofilm formed was collected from the other blocks. The concentration of acid-soluble $\mathrm{F}, \mathrm{Ca}$ and $\mathrm{P}_{\mathrm{i}}$, and the concentration of insoluble polysaccharide (IP) were determined in the dental plaque. Statistically lower concentrations of F, Ca and $\mathrm{P}_{\mathrm{i}}$, and a higher concentration of IP were found in the 28-day biofilm formed in the presence of sucrose than in its absence; after the treatment inversion the change in $\mathrm{F}, \mathrm{Ca}$ and $\mathrm{P}_{\mathrm{i}}$ was not statistically significant, but the IP concentration changed significantly. The hypothesis was rejected because change in concentration of $\mathrm{F}, \mathrm{Ca}$ and $\mathrm{P}_{\mathrm{i}}$ is not due to fermentation of the sucrose.
\end{abstract}

Key Words: caries, dental plaque, fluoride, polysaccharide, sucrose.

\section{INTRODUCTION}

Dental caries is a dietary-bacterial disease and sucrose is considered to be the most cariogenic carbohydrate because, apart from fermentation, it is also transformed into extracellular polysaccharide in dental plaque. The presence of these polysaccharides in biofilm also increases the dental plaque matrix porosity, enhancing the cariogenicity of sucrose (1).

However, Cury et al. $(2,3)$ recently showed that, in addition to the high concentration of insoluble polysaccharide, dental plaque formed in the presence of sucrose also shows a low concentration of fluoride $(\mathrm{F})$, calcium $(\mathrm{Ca})$, and inorganic phosphorus $\left(\mathrm{P}_{\mathrm{i}}\right)$. Thus, considering the importance of the inorganic composition of dental plaque to caries development (4), the factors responsible for the lower concentration of $\mathrm{F}, \mathrm{Ca}$ and $\mathrm{P}_{\mathrm{i}}$ in dental plaque formed in the presence of sucrose must be determined and several hypotheses have been formulated $(2,3): 1)$ repeated $\mathrm{pH}$ decreases, due to the fermentation of sucrose could have depleted plaque reservoirs of these ions, which then diffuse into the saliva; 2) the enamel could have incorporated the ions from the dental plaque during the cariogenic challenge; 3) lower bacteria density due to the large amount of insoluble polysaccharide, which in turn, results in few calcium-binding bacteria; 4) absence of anionic calcium-binding proteins or peptides. Data partially rejecting the first hypothesis were reported by Cury et al. (3); however, dental plaque was collected 12-h after the last exposure to sucrose and this period may not have been long enough for the released ions to replenish the plaque reservoirs.

Thus, the first hypothesis stated above was tested to evaluate whether the low concentrations of $\mathrm{F}, \mathrm{Ca}$ and $\mathrm{P}_{\mathrm{i}}$ found in dental plaque formed by repeated exposure to sucrose for 28 days would increase after this sugar exposure was interrupted for a longer time. As a control, we also evaluated whether the high concentrations of $\mathrm{F}, \mathrm{Ca}$ and $\mathrm{Pi}$ in dental plaque formed during 28 days 
in the absence of sucrose would decrease when exposure to this sugar was introduced.

\section{MATERIAL AND METHODS}

\section{Experimental Design}

The study involved a crossover, blind design performed in two phases of 30 days each. Eleven healthy adult volunteers took part in this study approved by the Research and Ethics Committee of FOP/ UNICAMP. They signed a written informed consent for participation.

Enamel blocks $(3 \times 3 \times 3 \mathrm{~mm})$ were prepared from impacted human third molars sterilized by immersion

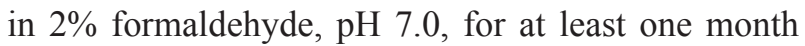
$(2,3,5)$. The surface of the enamel blocks was polished to remove a layer of $50 \mu \mathrm{m}(6)$. The volunteers wore custom-made acrylic palatal appliances each containing six dental enamel blocks placed as closely as possible to the posterior teeth; 3 blocks on each side of the appliance (anterior, central and posterior position on the left and right sides). A 4.0-mm-deep space was created in the acrylic appliance, leaving a $1.0-\mathrm{mm}$ space for plaque accumulation (3). For 28 days, dental plaque was allowed to form on the enamel blocks, which were protected from mechanical disturbance by a plastic mesh fixed to the acrylic surface. The volunteers were randomly assigned to one of two treatments: 8 times a day the appliances were removed and either $20 \%$ sucrose solution or distilled deionized water was dripped onto the enamel blocks. After $5 \mathrm{~min}$, the appliances were replaced in the mouth. A washout period of at least 7 days was allowed between the phases to eliminate possible residual effects from the treatments. During a 10-day pre-experimental period and during the experimental period, the volunteers brushed their natural teeth with non-fluoride toothpaste, but drank fluoridated water (0.6-0.8 $\mathrm{mg} \mathrm{F} / \mathrm{L})$. The volunteers received instructions to wear the appliances all the time, including at night, but to remove them during meals. The test subjects received oral and written information to refrain from using any antibacterial or fluoridated product during the pre-experimental and experimental periods. Considering that the study followed a crossover design, with the participation of the volunteers in both stages, the subjects did not receive any instructions regarding their daily diet.
The dental plaque formed on two opposite enamel blocks was collected with plastic curettes at three different periods of time $12 \mathrm{~h}$ after the last exposure to the solutions. The first collection, from anterior left and central right blocks, was made 28 days after the treatments. Immediately after this first plaque collection, the volunteers wore the appliances for $48 \mathrm{~h}$ longer, but the treatment was exchanged. Thus, the volunteers who had been dripping sucrose onto the blocks 8 times a day for 28 days started using water at the same frequency and vice versa. The second plaque collection, from central left and posterior right dental blocks, occurred $24 \mathrm{~h}$ after exposure to the solutions had been exchanged; the third collection, from posterior left and anterior right blocks, was made $48 \mathrm{~h}$ after the solution inversion. In the second stage of the study, the treatment was crossed for 28 days and exchanged for a further $48 \mathrm{~h}$.

\section{Analysis of Dental Plaque}

Dental plaque was placed in coded pre-weighed microcentrifuge tubes and the wet weight of each sample was determined to $\pm 10 \mu \mathrm{g}$. Hydrochloric acid $(0.5 \mathrm{M})$ was added to the tubes in the proportion of $50 \mu \mathrm{L} / \mathrm{mg}$ plaque wet weight. After extraction for $3 \mathrm{~h}$ at room temperature under constant agitation, the same volume of TISAB II pH 5.0 (containing $20 \mathrm{~g} \mathrm{NaOH} / \mathrm{L}$ ) was added as a buffer $(2,3)$. The samples were then centrifuged $(11,000 \mathrm{~g})$ for $1 \mathrm{~min}$ and the supernatant retained for determination of acid-soluble $\mathrm{F}, \mathrm{Ca}$ and $\mathrm{P}_{\mathrm{i}}$. To the precipitate, $1.0 \mathrm{~N} \mathrm{NaOH}(100 \mu \mathrm{L} / \mathrm{mg}$ plaque wet weight $)$ was added. The samples were vortexed for $1 \mathrm{~min}$, agitated for $3 \mathrm{~h}$ at room temperature and the concentration of insoluble polysaccharide (IP) in the resulting supernatant was determined. In the plaque acid extract, $F$ was analyzed using an ion-selective electrode (Orion 96-09; Boston, MA) and an ion analyzer (Orion EA940), Ca was analyzed by atomic absorption spectrophotometry using lanthanum to suppress interference and $\mathrm{P}_{\mathrm{i}}(7)$ and IP (8) were colorimetrically determined.

\section{Statistical Analysis}

Statistical analysis using the Shapiro-Wilks normality test detected heterogeneous variances in most of the variables. Thus, a nonparametric analysis was used for all variables, considering that variables with normal 
distribution show the same power when analyzed either by nonparametric or parametric tests. Wilcoxon test was used to compare 28-day dental plaque formed in the presence or absence of sucrose. The Friedman test was used to compare the effect of treatment inversion during the subsequent $48 \mathrm{~h}$ of biofilm formation. The non-parametric test of multiple comparisons was applied to determine significant differences among the experimental conditions. The relationship between $\mathrm{F}$, $\mathrm{Ca}$ and $\mathrm{P}_{\mathrm{i}}$ concentrations in dental plaque was evaluated by Pearson's correlation (9). For all analyses, the significance level was set at 5\%.

\section{RESULTS}

Data on inorganic composition and concentration of insoluble polysaccharide in 28-day dental plaque formed in the presence or absence of sucrose are re-

Table 1. Composition of dental plaque formed in the presence of sucrose for 28 days and changes after exposure interruption.

\begin{tabular}{lcccc}
\hline Conditions & $\begin{array}{c}\mathrm{F}, \mu \mathrm{g} / \mathrm{g} \\
(\mathrm{n}=8)\end{array}$ & $\begin{array}{c}\mathrm{Ca}, \mathrm{mg} / \mathrm{g} \\
(\mathrm{n}=9)\end{array}$ & $\begin{array}{c}\mathrm{P}_{\mathrm{i}}, \mathrm{mg} / \mathrm{g} \\
(\mathrm{n}=9)\end{array}$ & $\begin{array}{c}\mathrm{IP}, \mathrm{mg} / \mathrm{g} \\
(\mathrm{n}=11)\end{array}$ \\
\hline $\begin{array}{l}\text { Sucrose exposure } \\
\quad(28 \text { days })\end{array}$ & $1.1 \pm 0.3^{\mathrm{a}}$ & $1.2 \pm 0.7^{\mathrm{a}}$ & $0.2 \pm 0.04^{\mathrm{a}, \mathrm{b}}$ & $51.1 \pm 13.6^{\mathrm{a}}$ \\
$\begin{array}{l}\text { Sucrose interruption } \\
24 \mathrm{~h}\end{array}$ & & & & \\
$48 \mathrm{~h}$ & $1.6 \pm 0.4^{\mathrm{a}}$ & $1.6 \pm 0.6^{\mathrm{a}}$ & $0.2 \pm 0.06^{\mathrm{a}}$ & $49.7 \pm 11.4^{\mathrm{a}}$ \\
& $2.7 \pm 0.6^{\mathrm{a}}$ & $3.0 \pm 1.5^{\mathrm{a}}$ & $0.4 \pm 0.07^{\mathrm{b}}$ & $40.6 \pm 9.6^{\mathrm{b}}$ \\
\hline
\end{tabular}

Data are reported as average \pm SE.

Different letters indicate statistically significant differences $(p<0.05)$.

Table 2. Composition of dental plaque formed in the absence of sucrose for 28 days and changes after sucrose exposure.

\begin{tabular}{lcccc}
\hline Conditions & $\begin{array}{c}\mathrm{F}, \mu \mathrm{g} / \mathrm{g} \\
(\mathrm{n}=8)\end{array}$ & $\begin{array}{c}\mathrm{Ca}, \mathrm{mg} / \mathrm{g} \\
(\mathrm{n}=9)\end{array}$ & $\begin{array}{c}\mathrm{P}_{\mathrm{i}}, \mathrm{mg} / \mathrm{g} \\
(\mathrm{n}=9)\end{array}$ & $\begin{array}{c}\mathrm{IP}, \mathrm{mg} / \mathrm{g} \\
(\mathrm{n}=11)\end{array}$ \\
\hline $\begin{array}{l}\text { Sucrose absence } \\
(28 \text { days })\end{array}$ & $63.3 \pm 23.6^{\mathrm{a}}$ & $12.2 \pm 1.9^{\mathrm{a}}$ & $4.3 \pm 1.5^{\mathrm{a}}$ & $4.6 \pm 0.5^{\mathrm{a}}$ \\
$\begin{array}{l}\text { Sucrose exposure } \\
24 \mathrm{~h}\end{array}$ & & & & \\
$48 \mathrm{~h}$ & $86.1 \pm 38.6^{\mathrm{a}}$ & $18.8 \pm 4.5^{\mathrm{a}}$ & $4.9 \pm 1.3^{\mathrm{a}}$ & $10.0 \pm 2.7^{\mathrm{a}, \mathrm{b}}$ \\
& $67.9 \pm 37.5^{\mathrm{a}}$ & $14.8 \pm 4.0^{\mathrm{a}}$ & $3.9 \pm 1.1^{\mathrm{a}}$ & $11.4 \pm 2.3^{\mathrm{b}}$ \\
\hline
\end{tabular}

Data are reported as average $\pm \mathrm{SE}$.

Different letters indicate statistically significant differences $(\mathrm{p}<0.05)$. ported in Tables 1 and 2. Dental plaque formed in the presence of sucrose had a significantly lower concentrations of $\mathrm{F}, \mathrm{Ca}$ and $\mathrm{P}_{\mathrm{i}}$ and higher IP than that formed in its absence $(\mathrm{p}<0.05)$.

Tables 1 and 2 also show the results of $\mathrm{F}, \mathrm{Ca}, \mathrm{P}_{\mathrm{i}}$ and IP in dental plaque 24 and $48 \mathrm{~h}$ after the treatments were exchanged. The inorganic concentration neither increased (Table 1) nor decreased (Table 2) significantly when exposure to sucrose for $48 \mathrm{~h}$ was interrupted or started, respectively. The concentrations of $F$ and $\mathrm{Ca}$ did not change significantly $(\mathrm{p}>0.05)$ in either situation evaluated (Tables 1 and 2). With regard to $P_{i}$ concentration, the only statistically significant difference found was between $48 \mathrm{~h}$ after the interruption of sucrose exposure in comparison with $24 \mathrm{~h}$ (Table 1). The IP concentration fell in the dental plaque previously formed in the presence of sucrose when exposure to this sugar was interrupted for $48 \mathrm{~h}$ (Table 1). In contrast, IP concentration increased when dental plaque formed in the absence of sucrose for 28 days was exposed to this sugar for $48 \mathrm{~h}$ (Table 2).

Statistically significant correlations $(p<0.05)$ were found between concentrations $(\mathrm{mmol} / \mathrm{kg})$ of $\mathrm{F} \times \mathrm{Ca}, \mathrm{F} \times \mathrm{P}_{\mathrm{i}}$ and $\mathrm{Ca} \mathrm{x}$ $\mathrm{P}_{\mathrm{i}}$ both when the biofilm was formed in the presence of sucrose and when the exposure was interrupted (Table 3). This table also shows that a statistically significant correlation was found for $\mathrm{Ca} \times \mathrm{P}_{\mathrm{i}}$ both when the plaque was formed in the absence of sucrose for 28 days and after the exposure to this sugar for an additional $48 \mathrm{~h}$.

\section{DISCUSSION}

The inorganic composition of dental plaque matrix is potentially important in the development of dental caries (4). Thus, it is relevant to understand the mechanisms that lead to a lower concentration of $\mathrm{F}, \mathrm{Ca}$ and $\mathrm{P}_{\mathrm{i}}$ in biofilm formed in the presence of the cariogenic carbohydrate sucrose.

The present findings confirmed our previous studies $(2,3)$ showing that dental plaque formed during exposure to sucrose for 28 days resulted in biofilm with a low 
inorganic concentration of $\mathrm{F}, \mathrm{Ca}, \mathrm{P}_{\mathrm{i}}$ and a high IP content (Tables 1 and 2). Our findings are also in agreement with Pearce et al. (10) with regard to $\mathrm{Ca}$ and IP changes. However, the aim of this study was to evaluate the effect of repeated decreases in $\mathrm{pH}$ on the depletion of inorganic reservoirs present in dental plaque. Thus, if this low concentration of $\mathrm{F}, \mathrm{Ca}$ and $\mathrm{P}_{\mathrm{i}}$ were a simple consequence of decreased $\mathrm{pH}$ by sugar fermentation, the plaque reservoirs would be replenished again when the supply of sucrose was interrupted. By contrast, the high concentration of these ions in dental plaque formed in the absence of sucrose would be depleted when repeated exposure to this sugar was started.

Data in Tables 1 and 2 show that these ions neither increase nor decrease significantly in dental plaque when these conditions were tested. There are two known reservoirs in dental plaque that are sensitive to $\mathrm{pH}$ change: minerals (11) or Ca-F bridge bound to bacteria (12). The first reservoir would explain the change of $\mathrm{F}, \mathrm{Ca}$ and $\mathrm{P}_{\mathrm{i}}$, and the second would explain $\mathrm{F}$ and $\mathrm{Ca}$ changes by $\mathrm{pH}$. Thus, the present data suggest that the low inorganic concentration in biofilm formed in the presence of sucrose is a result of changes in the structure of the biofilm formed, rather than depletion of the inorganic pools by organic acids. The biofilm structure or unknown reservoirs seem to be the key answer to the binding of the ions. If the binding sites, such as anionic proteins or bacteria, are not available, then the simple interruption of a $\mathrm{pH}$ decrease will not allow favorable conditions for ion binding again. The high relationship found (Table 3) between $\mathrm{F}, \mathrm{Ca}$ and $\mathrm{P}_{\mathrm{i}}$, mainly when biofilm was formed in the presence of sucrose as opposed to its absence, suggests that the

Table 3. Pearson's correlation between $\mathrm{F}, \mathrm{Ca}$ and $\mathrm{P}_{\mathrm{i}}$ according to dental plaque formation.

\begin{tabular}{|c|c|c|c|}
\hline \multirow[t]{2}{*}{ Conditions } & \multicolumn{3}{|c|}{ Correlations [values of $r$ and $(p)$ ] } \\
\hline & $\mathrm{F} \times \mathrm{Ca}$ & $\mathrm{F} \times \mathrm{P}_{\mathrm{i}}$ & $\mathrm{Ca} \times \mathrm{P}_{\mathrm{i}}$ \\
\hline 28 days of sucrose exposure & $0.9817(0.0001)$ & $0.9803(0.0001)$ & $0.9920(0.0001)$ \\
\hline 28 days of sucrose absence & $-0.3192(0.4032)$ & $-0.4296(0.2481)$ & $0.7834(0.0125)$ \\
\hline $\begin{array}{l}28 \text { days of sucrose exposure } \\
\text { and } 48 \text { h of sucrose absence }\end{array}$ & $0.9959(0.0001)$ & $0.9451(0.0001)$ & $0.9602(0.0001)$ \\
\hline $\begin{array}{l}28 \text { days of sucrose absence } \\
\text { and } 48 \text { h of sucrose exposure }\end{array}$ & $0.5713(0.1080)$ & $0.4909(0.1795)$ & $0.9764(0.0001)$ \\
\hline
\end{tabular}

Concentrations in $\mathrm{mmol} / \mathrm{kg}$ structure of this biofilm is more complex than has been previously considered.

On the other hand, the findings could be explained by the fact that $48 \mathrm{~h}$ was too short a period to evaluate the change in the inorganic composition of biofilm. It may have been insufficient for the depleted plaque reservoirs of $\mathrm{F}, \mathrm{Ca}$ and $\mathrm{P}_{\mathrm{i}}$ to be replenished by these ions when the sucrose supply was interrupted, or for the release of the high amount of F, Ca and $\mathrm{P}_{\mathrm{i}}$ stored in plaque formed in the absence of sucrose. However, this possibility is small because kinetics data have shown that $\mathrm{F}$ concentration in dental plaque reaches or approaches baseline values at $12 \mathrm{~h}(13)$ or less $(14,15)$ after the use of dentifrice or mouth rinse. Furthermore, $\mathrm{Ca}$ and $\mathrm{P}_{\mathrm{i}}$ are natural ions in saliva and they may maintain a fine balance with the reservoirs of the mouth, including dental plaque.

Another explanation for the data is that F, Ca and $\mathrm{P}_{\mathrm{i}}$ concentration in dental plaque formed in the presence of sucrose for 28 days did not significantly increase when this sugar supply was cut off for $48 \mathrm{~h}$, due to the limited diffusion of these ions throughout this biofilm. Although the biofilm formed in the presence of sucrose is deeper than that formed in its absence, it is more porous and the diffusion from plaque is not a limitation (16). Furthermore, the concentration of F, Ca and $\mathrm{P}_{\mathrm{i}}$ may not have decreased when sucrose was supplied for $48 \mathrm{~h}$ to plaque formed for 28 days in the absence of sugar, due to the decrease in $\mathrm{pH}$ being limited to the outer part of the plaque.

Statistically significant differences were, however, observed with regard to the IP concentration in dental plaque (Tables 1 and 2). Thus, simultaneously to its decrease in concentration in 28-day dental plaque which had been formed in the presence of sucrose, when the supply of this sugar was interrupted (Table 1), it increased when the exposure to sucrose started for $48 \mathrm{~h}$ (Table 2). The decrease in IP concentration could not be explained by the breakdown of these polysaccharides for energy production because they have a structural function and are not easily metabolized. This reduction could, however, be a consequence of the 
formation of a new layer of dental plaque which, since formed in the absence of sucrose, would not be able to synthesize IP. Thus, the IP formed for 28 days, by exposure to sucrose, would have been diluted by the de novo plaque formed for $48 \mathrm{~h}$ in the absence of this sugar. However, we did not find any statistically significant difference between the wet weights of these plaques ( $\mathrm{p}=0.0943$; data not shown). It is also possible that the alkali extracted some degradable extracellular polysaccharide that had been trapped in the plaque matrix, but was resistant to the first extraction with acid.

The increase in IP when the supply of sucrose was started can, however, be explained because this type of polysaccharide is exclusively synthesized in the presence of this carbohydrate. Thus, IP is formed at the same time that sucrose is utilized as a source of energy for the growth of a new biomass of plaque. We found that the 28-day plaque wet weight formed in the absence of sucrose increased significantly from 6.46 to $9.79 \mathrm{mg}(51 \%)$ after $48 \mathrm{~h}$ of sucrose supply ( $\mathrm{p}=0.0256$; data not shown) and IP had a statistically significant increase of $60 \%$ (Table 2).

In conclusion, the findings of the present study suggest that the low concentration of $\mathrm{F}, \mathrm{Ca}$ and $\mathrm{P}_{\mathrm{i}}$ observed in dental plaque formed in the presence of sucrose cannot be explained by the repeated $\mathrm{pH}$ decrease due to the acid production from fermentation of this carbohydrate. It may be explained by structural changes in dental plaque formed and research in this direction is in progress.

\section{ACKNOWLEDGEMENTS}

A.S. Marques was the recipient of a $\mathrm{CNPq}$ scholarship (PIBIC-CNPq-UNICAMP) during her undergraduate course in Dentistry. The skillful technical assistance of Mariza J.C. Soares and Waldomiro V. Filho is gratefully acknowledged. The authors wish to thank the volunteers for their valuable participation in this study.

\section{RESUMO}

Desde que os reservatórios de flúor $(\mathrm{F})$, cálcio $(\mathrm{Ca})$ e fósforo inorgânico $\left(\mathrm{P}_{\mathrm{i}}\right)$ na placa dental são suscetíveis a quedas de $\mathrm{pH}$, este estudo in situ cruzado foi conduzido para testar a hipótese de que baixas concentrações destes íons na placa, formada na presença de sacarose, poderiam ser atribuídas simplesmente à fermentação deste açúcar. Onze voluntários utilizaram dispositivos palatinos contendo seis blocos de esmalte dental humano durante duas fases. Em cada fase os tratamentos foram solução de sacarose a $20 \%$ ou água destilada deionizada, que foram gotejadas sobre os blocos 8 vezes ao dia. Após 28 dias, em cada fase, a placa dental formada sobre dois blocos foi coletada, o tratamento foi invertido e após um tempo adicional de 24 e 48 horas, o biofilme formado foi coletado dos outros blocos. A concentração de $\mathrm{F}, \mathrm{Ca}$ e $\mathrm{P}_{\mathrm{i}}$ solúvel em ácido e a concentração de polissacarídeo insolúvel (PI) foram determinadas na placa dental. Concentrações estatisticamente menores de $\mathrm{F}, \mathrm{Ca}$ e $\mathrm{P}_{\mathrm{i}}$, e uma concentração maior de PI foram encontradas no biofilme de 28 dias formado na presença de sacarose do que na sua ausência; após a inversão do tratamento a mudança no $\mathrm{F}, \mathrm{Ca}$ e $\mathrm{P}_{\mathrm{i}}$ não foi estatisticamente significante, mas a concentração de PI mudou significativamente. A hipótese foi rejeitada porque a mudança na concentração de F, Ca e $\mathrm{P}_{\mathrm{i}}$ não é devida à fermentação da sacarose.

\section{REFERENCES}

1. Dibdin GH, Shellis RP. Physical and biochemical studies of Streptococcus mutans sediments suggest new factors linking the cariogenicity of plaque with its extracellular polysaccharide content. J Dent Res 1988;67:890-895.

2. Cury JA, Rebello MAB, Del Bel Cury AA. In situ relationship between sucrose exposure and the composition of dental plaque. Caries Res 1997;31:356-360.

3. Cury JA, Rebello MAB, Del Bel Cury AA, Derbyshire MTVC, Tabchoury CPM. Biochemical composition and cariogenicity of dental plaque formed in the presence of sucrose or glucose and fructose. Caries Res 2000;34:491-497.

4. Pearce E. Plaque minerals and dental caries. N Z Dent J 1998;94:12-15.

5. White DJ. Reactivity of fluoride dentifrices with artificial caries. I. Effects on early lesions: F uptake, surface hardening and remineralization. Caries Res 1987;21:126-140.

6. Featherstone JDB, Zero DT. An in situ model for simultaneous assessment of inhibition of demineralization and enhancement of remineralization. J Dent Res 1992;71:804-810.

7. Fiske CM, Subbarow Y. The colorimetric determination of phosphorus. J Biol Chem 1925;66:375-400.

8. Dubois M, Gilles KA, Hamilton JK, Rebers PA, Smith F. Colorimetric method for determination of sugars and related substances. Analyt Chem 1956;28:350-356.

9. Ayres M, Ayres Jr M, Ayres DL, Santos AS. BioEstat 2.0: Statistical Applications in Biological Sciences and Medicine (In Portuguese). Belém, Sociedade Civil Mamirauá; Brasília, CNPq, 2000.

10. Pearce EI, Sissons CH, Coleman M, Wang X, Anderson AS, Wong $\mathrm{L}$. The effect of sucrose application frequency and basal nutrient conditions on the calcium and phosphate content of experimental dental plaque. Caries Res 2002;36:87-92.

11. Kaufman HW, Kleinberg I. X-ray diffraction examination of calcium phosphate in dental plaque. Calcif Tissue Res 1973;11:97-104.

12. Rose RK, Shellis RP, Lee AR. The role of cation bridging in microbial fluoride binding. Caries Res 1996;30:458-464.

13. Whitford GM, Wasdin JL, Schafer TE, Adair SM. Plaque fluoride concentrations are dependent on plaque calcium concentrations. Caries Res 2002;36:256-265.

14. Bruun C, Givskov H, Thylstrup A. Whole saliva fluoride after toothbrushing with $\mathrm{NaF}$ and MFP dentifrices with different $\mathrm{F}$ 
concentrations. Caries Res 1984;18:282-288.

15. Oliveby A, Weetman DA, Geddes DAM, Lagerlöf F. The effect of salivary clearance of sucrose and fluoride on human dental plaque acidogenicity. Arch Oral Biol 1990;35:907-911.

16. McNee SG, Geddes DA, Weetman DA, Sweeney D, Beeley JA.
Effect of extracellular polysaccharide on diffusion of $\mathrm{NaF}$ and (14C)-sucrose in human dental plaque and in sediments of the bacterium Streptococcus sanguis 804 (NCTC 10904). Arch Oral Biol 1982;27:981-986. 